\title{
Does the acquisition of aspect have anything to do with aspectual pairs?*
}

\author{
Natalia Gagarina \\ ZAS Berlin \\ gagarina@zas.gwz-berlin.de
}

\begin{abstract}
The purpose of this research was to trace the developmental steps in the acquisition of aspectual oppositions in Russian and to examine the validity of the 'aspect before tense' hypothesis for L1-speaking children. Imperfective/perfective verbs and their inflections, as well as aspectual pairs, were analysed in the first five months of verb production (and the respective months in the input) in three children. Additionally, the first four months of verb production were investigated in one boy with less data. Verb forms marked for the past and for the present occur simultaneously in all children. These early forms relate to 'here and now' situations: verbs marked for the past denote 'resultative' events that are perceived by the children as occurring during the speech time or immediately before it, while verbs marked for the present typically denote on-going events. Thus, with early tense oppositions (or tense morphology) children mark aspectual contrasts in the moment of speech: evidence in favour of the 'aspect before tense' hypothesis.

A strong preference in using the perfective aspect for the past and the imperfective aspect for the present events has been found in both adults and children. Further, only very few aspectual pairs were documented within the analysed period (from the onset of verb production to the period when children produce rule-driven inflectional forms). The productive use of the finite forms of perfective and imperfective verbs doesn't concord with the ability of the productive use of the contrastive forms of one lemma. Data suggest that children (start to) learn aspectual forms in an item-based manner. The acquisition of aspectual oppositions (aspectual pairs) is lexically dependent and is guided by the contextual 'thesaurus'. Aspectual pairs are learned in a peace-meal way during much longer, than observed for this article, period of time. Generally, aspect is not learned as a rule, also because there are no (uniform) rules of forming of aspectual pairs, but as the 'satellite' of the inherent lexical meaning of verbs of diverse Aktionsarten.

The issues addressed here are relevant for other Slavic languages, exhibiting the morphological category of aspect.
\end{abstract}

\section{Introduction}

\subsection{Aspect in language acquisition}

In the last decades numerous psycholinguistic studies have been concerned with the acquisition of aspect (and tense). Findings of these studies (as well as the general Aspect Hypothesis discussed in these studies) very thoroughly and in detail reviewed in Weist 2002 (see also Shirai 1998, 2003). Trying to avoid the repetition of these reviews I address only the most relevant for this paper points. One of them indicates that

I'm very grateful to Eva Bar-Shalom for her careful reading and helpful commenting on this paper. My thanks go also to Katharina, Wilhelm Geilen and Maria Luise Crevett for their immense 'non-linguistic' support during the work on this article. All mistakes are mine. 
in languages, possessing the perfective/imperfective distinction, imperfective past develops later than perfective past and imperfective past marking is used predominantly with stative and activity verbs (Shirai 1998:282, from Weist 2002:60).

Data from two Romance languages, Spanish and Italian, confirm this statement (MuellerGarthercole et al. 1999, Antinucci and Miller 1976, etc.). Data obtained from the two Slavic languages ${ }^{1}$, Polish and Russian seem to be in, at least some, discordance with it. Polish data (Smoczyńska 1985, Weist et al. 1984,) show that

imperfective forms are among the earliest verb forms, but simple token frequencies provide minimal information about productivity (Weist 1984:354-355).

Russian data (Poupynin 1998, Gagarina 1997, 2003, but not Kiebzak-Mandera 1999) indicate the later emergence and the infrequent occurrence of the imperfective (henceforth, ipf) past ${ }^{2}$ in comparison with the ipf present and perfective (henceforth, pf) past (more on this issue see section 3.2). ${ }^{3}$ On the contrary, the detailed study of Bar-Shalom (2002) on the development of tense and aspect morphology in early child Russian showed that youngest children

have mastered deictic tense relations as evidenced by the production of each tense in the appropriate contextual circumstances (Bar-Shalom 2002:335).

Bar-Shalom (2002) argues against the aspect first hypothesis and shows no evidence for Wagner's (2001) proposal that grammatical aspect affects children's comprehension of the past tense.

An inseparable part of the 'aspect hypothesis' deals with Vendler's (1967) states, activities, accomplishments, and achievements and their inflections. However, the direct application of these four classes onto Russian (and other Slavic languages exhibiting the category of morphological aspect) is dubious (more on this issue see Dahl 1974, Kucera 1983, Mehlig 1981, Petruhina 2000, Gagarina 2001, also section 1.3), partially, due to the presence of aspectual pairs. There seems to be no problems with states-imperfectiva tantum, like ljubit' 'love' and achievements-perfectiva tantum, like ochutit'sja 'find oneself' which do not form aspectual pairs. Atelic activities may attain telicity in Russian (except for verbs of motion) and English in a similar way by object assignment, i.e. pet' 'sing', pet' pesn' $u$ 'sing a song'. The 'rest' of the ipf and pf verbs form aspectual pairs and don't undergo this classification. For example, the verb fall has two equivalents in Russian: padat'-ipf and upast'-pf. The ipf verb denotes an action that may have some duration and an inherent inclination to reach an endpoint, therefore it belongs to the group of accomplishments, while its pf counterpart denotes an action which is reducible to a single point in time, i.e. takes place instantaneously, and thus stays in the same group of achievements as the English fall.

Weist, Pawlak, and Carapella (2004) elaborated the Lexical aspect assignment rules for Polish in order to sort out predicates into atelic and telic categories ${ }^{4}$. However, their application for Russian is in a way also blocked by aspectual pairs. It is demonstrated with an example of the verb jechaćlpoechać (Polish) 'to go by vehicle', considered in Weist, Pawlak, and Carapella (2004:44); Russian equivalent ehat'. This one-directional telic ipf verb of motion in Russian may form a pair with the verb prijehat' 'to come/arrive by vehicle-pf'. The pf pojehat' is not a counterpart to ehat' and cannot be treated in Russian as

1 Relatively less has been done (at least published in English) on this issue in Slavic languages, in generally, and in Russian, specifically.

2 Cf. Katičić 2003:246 for Croatian.

3 Generally, it has been found that past ipfs are infrequently used also in adults in these two languages.

4 Compare with the set of tests that help to "classify verb phrases according to Vendler-type schemas" (Weist et al. 1984:352). 
an active-accomplishment involving motion to a goal (Weist, Pawlak, and Carapella (2004:44))

in sentences like 'poedeš' v gorod?' 'go-pf:pres: $2 \mathrm{~s}{ }^{5}$ where it denotes the intention to perform the (inception of the) action in the nearest future as a single and undividable whole. The pf verb may be substituted with the ipf equivalent without the basic change of its telic meaning: edeš' $v$ gorod? 'go-ipf:pres:2s'. The next two sections will survey this issue in more detail.

\subsection{Aspect in adult Russian}

Traditionally, the descriptions of the Russian verbal system stress that aspect 'runs' like a red thread through the whole verbal system and influences it. This means that each verb form (verb lemma), non-finite and finite, belongs to either the $\mathrm{pf}$ or the $\mathrm{ipf}^{6}$ aspect. The $\mathrm{pf}$ aspect, a semantically marked member of the aspectual opposition, denotes an event in its totality, thus, determines boundaries of this event. ${ }^{7}$ The ipf aspect 'leaves open' the presence of the event boundaries, and its interpretation (strongly) depends on the sentential context, i.e. whether an ipf verb denotes a telic or an atelic event is determined by the 'syntactical environment'. Basically, one can recognise aspects on the verbal stem, and native speakers of Russian may do it intuitively without any difficulties by putting a question čto sldelat' 'what to do-pflipf' to a verb. The verbal aspect is then determined on the basis of the answer to either the question, e.g. čto delat'-ipf? pet' 'sing-ipf' or čto sdelat-pf? spet' 'sing-pf'; popet' 'sing for a while-pf'; zapet' 'start singing-pf'.

Most verbs tend to form aspectual pairs in Russian. Thus, an English verb translated into Russian will have two 'equivalents', two counterparts, e.g. drink $\rightarrow$ ipf pit' and pf vypit', with pit' and vypit' being two different, though related, verbs rather than the inflectional forms of the same verb. Some verbs do not form aspectual pairs, e.g. perfectiva tantum (kashl'anut' 'cough once', ochutit'sja 'find oneself somewhere suddenly') and imperfectiva tantum (l'ubit' 'love'). And, finally, the increasing number of (loan) verbs ${ }^{8}$ add to the class of bi-aspectual verbs, where the determination of aspect in a neutral context isn't possible (cf. Čertkova, 1996), e.g. issledovat' 'research'. ${ }^{9}$ Further, numerous Aktionsarten are treated as a lexical aspect.

Such a sketch seems to be satisfactory enough for the purposes of investigation of (the acquisition of) the verbal aspect. However, the 'concealed part' of an 'aspectual' iceberg which can cause problems in the later investigations often remains without attention. One of them is under analysis in the present study: aspectual pairs and their counterparts.

5 This example is taken from Weist, Pawlak, and Carapella (2004:44) is

'(Auntie-VOC, PFV-go-2:S with us to Łódź-GEN)

(Auntie, will you go with us to Łódź?)'.

6 With exceptional instances of bi-aspectual verbs, e.g. issledovat' 'investigate'.

$7 \quad$ The pf aspect is used only in the past and future. The ipf aspect is used in the past, present, and future.

8 Nowadays their amount has increased to several thousands, and $90 \%$ of all bi-aspectual verbs are neologisms.

9 There is a tendency in contemporary Russian not to express bi-aspectuality. Many of the new bi-aspectual verbs become perfectivised, e.g. unificirovat'|sunificirovat' 'to unify-ipflpf'. 


\subsection{Aspectual pairs in adult Russian}

\subsubsection{The nature of aspectual pairs}

The discussion of the nature of an aspectual pair and the issue whether the two members of a pair are different verbs or forms of one verb has a very long history and dates back, at least to the beginning of the twentieth century in the Russian tradition (cf. Vinogradov 1938, Šahmatov 1941, etc.). Three major contrasting views on the nature of counterparts within a pair are known. Two of them contrast the most: the cases where counterparts are forms of one verb (e.g. Vinogradov 1938) and those where counterparts are two different verbs (e.g. RG80). The third view examines pairs with the derived ipfs, secondary imperfectivisation, and treats them as the forms of one lemma (e.g. Bondarko 1983). I would tend to consider the members of an aspectual pair as two different, though related, verbs rather than the inflectional forms of the same verb. Several arguments (apart from the view presented above) may support this point of view. In different types of dictionaries (like Russian-English dictionary, Explanatory dictionary, etc.) two counterparts are usually given as two lexical entries each with its 'own' inflection and forms. Further, none of the counterparts build the full paradigm; in other words the paradigm of a pr or ipf verb is defective (see Isačenko 1968) and may be full only as a community-unit of the two verbs. Besides, counterparts have different argument structure and 'behave' differently within a sentence.

The choice of one or another view/position has strong implications for the acquisitionists dealing with the learning of aspect and addressing the issue of how the aspectual distinctions (and aspect itself) are acquired: on item by item basis or are they rule-based?

\subsubsection{Semantic types of aspectual pairs}

The next two sections provide a preliminary sketch attempting to evaluate different semantic and structural types of aspectual pairs. As I mentioned earlier, each verb belongs to one of the aspects, but not all verbs form an aspectual pair (a pair of lexically similar verbs, which are differentiated only by aspectual semantics). The ability to do this depends on the lexical inherent meaning of a verb: only ipfs with (potentially) telic reading may form aspectual pairs. ${ }^{10}$ Moreover, the 'lexical' nature of an ipf verb determines the possible range of its meanings in a sentence and a semantic type of a pair. ${ }^{11}$

An aspectual pair may consist of a telic ipf verb denoting a durative event involving an inclination to reach a critical terminal point (after which the event may stop) and a pf counterpart denotes the attainment of this critical point, e.g. staret'lpostaret' 'become oldipflpf', vstavat'|vstat' 'stand up-ipflpf', est'|s' 'est' 'eat-ipflpf', etc.

Other pairs may consist of verbs denoting an undividable single whole event. Ipfs in these pairs don't basically have a progressive meaning (and, thus, may often concur - occur intercheangably - with perfectives in the past) and may denote past habitual or generalisedfactual events, e.g. brat'|vzjat' 'take'12, sluchat'sjalsluchit'sja 'happen', terjat'|poterjat'

\footnotetext{
10 A basic verb in pairs under consideration below is a simplex imperfective. All pf verbs denote an action (or a part of an action) as a bounded whole, e.g. they are telic. I do not consider here the most regular secondary imperfectivisation, attachment of the suffix $-y v a /$-iva to pfs.

11 In some cases a prefixed derivation of a pair contains the common semantic element for both the prefix and the verb, e.g. example from RG-80:586 pahat' 'plough' and $v z$ - have the common element of the meaning of 'movement upwards'.

12 In the aspectual pairs I usually present first the ipf verb and then the pf verb.
} 
'loose', vkljuchat'|vkljuchit' 'switch on', etc. The difference between the telic reading of such ipfs and pfs in the past is in the definiteness/'concreteness' of a denoted event. Thus, both ipf and pf verbs smotrel posmotrel 'see' refer to a terminal event (examples 1a,1b), but the ipf denotes a generalised event and the pf denotes a concrete event (and the definite NP) (see Bondarko 1990, 1995 on the meanings of aspects):

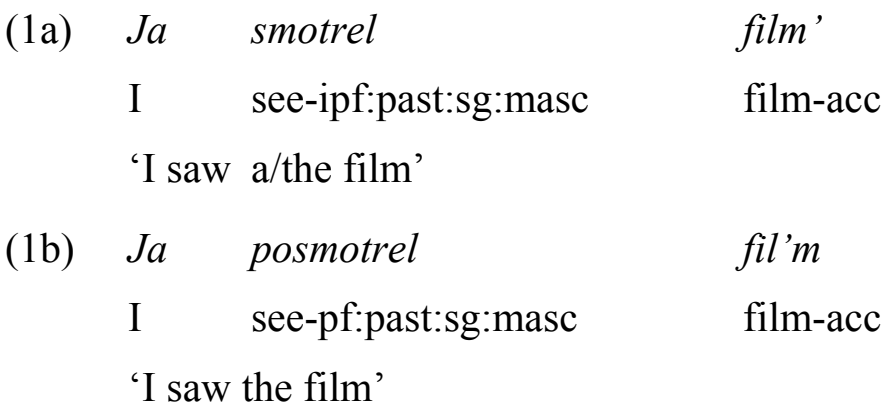

Further, there is a (small) group of atelic ipf activity (Vendler's classification) verbs like pet' 'sing', igrat' 'play', etc. ${ }^{13}$ that may be transformed into accomplishments (and attain telic reading) in contexts with count nouns (the counterparts in this case are not similar in their argument structure: an object is obligatory with the pf verb), see examples $2 \mathrm{a}-\mathrm{d}$ :

$\begin{array}{llll}\text { (2a) } & \text { On } & \text { pel } & \\ & \text { He } & \text { sang-ipf (telic)/was singing-ipf (atelic) }{ }^{14} \\ \text { (2b) } & \text { *On } & \text { spel } & \\ & \text { He } & \text { sang-pf } & \text { pesnju } \\ \text { (2c) } & \text { On } & \text { pel } & \text { a/the song } \\ & \text { He } & \text { sang/was singing-ipf } & \text { pesnju } \\ \text { (2d) } & \text { On } & \text { spel } & \text { a/the song }\end{array}$

Some atelic ipf verbs (states and activities, in Vendler's 1967 classification), due to their semantic specificity are not able to denote a tendency to/attainment of a terminal endpoint and don't form aspectual pairs, e.g. stojat' 'stand', spat' 'sleep', granichit' 'border', hodit' 'go by foot-multidirectional', etc. These ipf verbs (RG-80:583-584) may have a pf form with an additional lexical meaning, e.g. bolet' 'be sick' - zabolet' 'be sick-ingressive-pf', pobolet' 'be sick-delimitative-pf', etc. Further, ipf verbs of motion, like hodit' 'go by footmultidirectional' do not change their aspect while adding a prefix, uhodit' 'go-by foot away', perehodit' 'cross the street by foot', prihodit' 'come by foot', etc.

\footnotetext{
13 Twelve one-directional motion verbs, which belong in Vendler's classification to atelic activities, are telic in Russian: idti 'go by foot', bezhat' 'run', ehat' 'go by car', etc.

14 The aspectual meaning of the sentences may be, for example, determined by the constellation of various devices of syntax and discourse (e.g. Dowty 1972, Verkuyl 1993). In Russian, aspectuality not only operates on the level of sentence, but 'can be even expressed without a verb' (Gagarina 2000:232). The detailed investigation of this issue is beyond the scope of this article.
} 
Based on our analysis, we come up with four different types of pairs given in the Table 1:

\begin{tabular}{|c|c|c|}
\hline ipf & $\mathrm{pf}$ & verb \\
\hline $\begin{array}{l}\text { - duration } \\
+ \text { telicity } \\
(\mathrm{ACH})\end{array}$ & \multirow{5}{*}{$\begin{array}{c}- \\
\text { duration } \\
+ \\
\text { telicity } \\
(\mathrm{ACH})\end{array}$} & happen, meet, switch on/off, take \\
\hline $\begin{array}{c}+ \text { duration } \\
+ \text { telicity } \\
\text { (ACC) }\end{array}$ & & $\begin{array}{l}\text { catch, grow, stand up, open, persuade, wake, return, run } \\
\text { (one-directional), go (one-directional), }\end{array}$ \\
\hline $\begin{array}{c}+ \text { duration } \\
+ \text { telicity } \\
+ \text { incremental } \\
\text { theme } \\
\text { (ACC) }\end{array}$ & & build, eat, load, read \\
\hline $\begin{array}{l}\text { + duration } \\
+/- \text { telicity }\end{array}$ & & sing, draw \\
\hline $\begin{array}{l}\text { context) } \\
(\mathrm{ACT})\end{array}$ & & (cry, run (multidirectional), go (multidirectional) ${ }^{15}$ ) \\
\hline
\end{tabular}

Table 1. Ipf and pf verbs forming aspectual pairs

The question addressed below is what types of pairs are predominant (if any) in the period investigated (the onset of verb production), with what inflection do the counterparts of each type of the pair are used? Do children generally have any preferences in any type of aspectual pairs?

\subsubsection{Structural types of aspectual pairs}

Aspectual counterparts like čitat'|pročitat' 'read', pisat'|napisat' 'write', stroit'|postroit' 'build' are predominantly cited in studies dealing with the aspect in Russian. 'Unpleasant' types stay beyond citations. Usually (with some exception, e.g. Stoll 1998) no further specification of the structural types of these aspectual pairs, their similarities and differences with regard to the types of the aspectual markers participating in aspect formation is given. One of the problems is that there is no unique (and even no definite and predictably applicable) set of grammatical operators for the perfectivation process (there is $-i v a /-y v a$ for the second imperfectivisaton). As Filip (1999:181) pointed out

the rich lexical semantics of verbal prefixes ... was and is still considered to be one of the main obstacles to characterizing the semantics of all perfective verbs in a common way;

besides, further regularities in (im)perfectivisation (the formation of aspectual pairs)

so far escaped any truly systematic and revealing description (Filip 1999: 183).

Since the way the pair is formed is important for the acquisitional process (and refers to the question whether aspect is learned as a rule or in a lexically-based way), I treat it in more detail.

Aspectual pairs in Russian may be formed by means of prefixation, suffixation and suppletion, see Tables 2 and 3. Within each of three types various sub-types may be distinguished. ${ }^{16}$

15 The verbs given in brackets and marked with a cursive are atelic and do not form aspectual pairs. 


\begin{tabular}{|l|l|l|l|l|}
\hline & ipf & pf & second ipf & translation \\
\hline 1. prefixation & dela-t' & $\underline{\text { s-dela-t’ }}$ & & do \\
\hline & pisat' & na-pisat' & & write \\
\hline & čitat' & pro-čhitat' & prochityvat' & read \\
\hline & & total: 15 prefixes & & \\
\cline { 2 - 5 } & & & & \\
\hline
\end{tabular}

Table 2. Structural types of aspectual pairs: prefixation

Prefixation is characterised by the highest divergence. Within this type 18 subtypes are distinguished according to the number of productive verbal prefixes, existing in Russian: $v$ (vo), vz- (vs, vzo), vy-, do-, za-, iz-(is, izo), na-, nad-(nado), o- (ob ,obo), ot-(oto), pere-, po-, pod-(podo), pri-, pro-, raz-(ras, razo), s- (so), u- (Isačenko 1968: 357, 15 prefixes - RG-80: 587-588). Actually, each prefix may derive a pf verb (without an additional (or with minimum) lexical meaning) from an ipf one. However, it's not possible to predict with what type of verb lexeme a given prefix will be 'pure-aspectual' and with which stems it will be not 'pure-aspectual'. Besides it is not predictable whether a given prefix may be combined with a certain ipf verb.

Some prefixes may obtain pure-aspectual meaning more frequently, some - less. But, generally, the grammatical function of prefectivisation of none of the above prefixes can be said to be independent from lexical meaning. ${ }^{17}$ Further, different prefixes may form an aspectual pair depending on the argument of a verb, e.g. varit' 'cook-ipf' (see Table 2) vyvarit' 'cook-ipf' or svarit' 'cook-pf' (however, suffix vy-with a pf verb modifies its lexical meaning, but doesn't change its aspect e.g. brosit' 'throw-pf', vybrosit' 'throw away-pf').

\begin{tabular}{|l|l|l|l|l|}
\hline ipf & translation & pf & object & translation \\
\hline varit' & cook & paz-varit $^{\prime}$ & meat & cook meat \\
\hline & & ot-varit' & potatoes & cook potatoes \\
\hline
\end{tabular}

\begin{tabular}{|l|l|l|l|l|}
\hline ipf & translation & direct object & pf & translation \\
\hline rezat' & cut & rope & raz-rezat'verjovku & cut rope \\
\hline & & bread & na-rezat' hleb & cut bread \\
\hline
\end{tabular}

Table 3. Formation of the pairs by means of prefixation: rezat' 'cut' and varit' 'cook'

Consider another similar example, where the information about a specific type of an action denoted by an ipf verb can be obtained only after the pf verb at the end of a sentence:

$\begin{array}{lll}\text { On } \quad \text { rval-ipf } \quad \text { leibl } i \quad \text { nakonec } & \text { porval-pf } \\ & & \\ & \text { otorval-pf } f^{89} \\ & & \text { vyrval-pf }\end{array}$

Cf. Filip 1999:177-178 for Czech.

17 Prefix po- is considered to be the most semantically neutral prefix, cf. Comrie 1976, Filip 1999:192.

18 The verb otorvat'-pf possesses the secondary impf otryvat'.

19 The verb vyrvat'-pf possesses the secondary ipf vyryvat'. 
He was-tearing label and finally tore

it

tore-off

tore-out

Even within a single semantic subgroup of verbs one and the same prefix may obtain either a pure-aspectual or a semantic meaning depending on a verb lemma, e.g. stroit'postroit' 'build', but risovat'|narisovat' 'draw', porisovat' is delimitative and means 'draw a bit-pf'. ${ }^{20}$ So, for this type of a pair formation there is no formal common rule regulating what prefixes derive pfs from their ipf counterpart and under what condition these prefixes may be pureaspectual. This makes it necessary for children to acquire each pair (and each member of a pair) as a separate 'lexical entry'.

Formation of aspectual pairs by means of suffixation differs from prefixation in that it a) presents the more regular and uniform pattern, b) shows the stable identity of the lexical meanings of counterparts. For example, from almost all pf verbs with the prefix $-v$ having the meaning of the movement inside, second ipfs may be formed: vvintit'lvvinchivat' 'screw inpflipf'. Generally, from prefixed pfs (which were derived from respective ipfs) a secondary ipf may be formed with the iterative suffix $-y v a-(i v a)$, see Table 4, section 2. Secondary imperfectivisation (by means of suffixes $-y v a /-v a$ ) of the pfs with the 'pure-aspectual suffix' yields synonymic connection between the basic, first, and the second ipfs: slabet'loslabet' 'become weaker-ipflpf' $\rightarrow$ oslabevat'-ipf.

\begin{tabular}{|c|c|c|c|c|}
\hline & ipf & $\mathrm{pf}$ & ipf & translation \\
\hline \multicolumn{5}{|l|}{ 2. suffixation } \\
\hline 2.1. -iva/-yva-second imperfectivisation & & $\begin{array}{l}\text { peredelat' } \\
\text { peredarit' }\end{array}$ & $\begin{array}{l}\text { peredelyvat' } \\
\text { peredarivat, }\end{array}$ & $\begin{array}{l}\text { redo } \\
\text { represent }\end{array}$ \\
\hline $\begin{array}{l}2.2 .-v a \\
(3 \text { verbs })\end{array}$ & & $\begin{array}{l}\text { dat' } \\
\text { det' }\end{array}$ & $\begin{array}{l}\text { davat' } \\
\text { devat' }\end{array}$ & $\begin{array}{l}\text { give } \\
\text { put }\end{array}$ \\
\hline \multicolumn{5}{|l|}{ 3. suppletion } \\
\hline $\begin{array}{l}\text { 3.1. full } \\
\text { (ca. } 10 \text { pairs Isačenko } 1968: 354 \text { ) }\end{array}$ & brat' & vzjat’ & & take \\
\hline 3.2. partial suppletion - stem alternation & $\begin{array}{l}\text { leč' } \\
\text { sest' } \\
\text { stat' } \\
\text { dostič }\end{array}$ & \begin{tabular}{l|} 
ložit'sja \\
sadits'ja \\
stanovit'sja \\
dostigat'
\end{tabular} & & $\begin{array}{l}\text { lie down } \\
\text { sit down } \\
\text { become } \\
\text { reach }\end{array}$ \\
\hline 3.3. partial suppletion - root vowel alternation & & $\begin{array}{l}\text { zabrat' } \\
\text { ubrat' } \\
\text { umeret' }\end{array}$ & $\begin{array}{l}\text { zabirat' } \\
\text { ubirat' } \\
\text { umirat' }\end{array}$ & $\begin{array}{l}\text { take } \\
\text { put away } \\
\text { die }\end{array}$ \\
\hline $\begin{array}{l}\text { 4. conjugation (thematic suffix) } \\
\text { (26 pairs Isačenko } 1968: 352-353 \text { ) }\end{array}$ & \begin{tabular}{|l|} 
reshat' \\
vključat'
\end{tabular} & $\begin{array}{l}\text { reshit' } \\
\text { vključit' }\end{array}$ & & $\begin{array}{l}\text { solve } \\
\text { switch on }\end{array}$ \\
\hline 5. stress & nasyp At' & nasYpat' & & pour in \\
\hline
\end{tabular}

Table 4. Structural type of aspectual pairs: suffixation and suppletion

The rest of the types of pairs (Table 4, sections 3-5) are irregular and include suppletion, conjugation and stress. So, pairs formed on the basis of a more regular pattern (and exhibiting

20 Prefixation is the most productive type of pair formation in modern Russian (see Gagarina 2002). From loan verbs, originally entering the spoken language as ipfs, pf counterparts are derived by means of a 'prefix operator': to help > helpit'-ipf, counterpart za-helpit'-pf, to use > jusat '-ipf, counterpart za-juzat '-pf. 
minimal lexical changes) have 'more chances' to be learned as a rule. However, exactly these types of pairs, as the discussion below will show don't appear within the period analysed. ${ }^{21}$

Assignment of an aspectual pair to one of the types is crucial for the question whether counterparts are one lemma or not.

\subsubsection{Aspectual pairs: distribution within a continuum?}

It seems that types of aspectual pairs, regarding a) the regularity of the application of the morphological rules in their formation, b) similarity of their morphophonological changes, c) productivity of a pattern in the target language, and d) telic-atelic nature of a basic ipf may be presented as a distribution on a continuum one border of which nears the lexical pole and another border - the grammatical pole. Thus, different type of pairs will occupy the following positions on the continuum axe:

Lexical pole

Grammatical Pole

\begin{tabular}{|c|c|c|}
\hline suppletion & ipf $v$ is a base of a pair $\rightarrow$ prefixation & $\begin{array}{l}\text { pf } \mathrm{v} \text { is a base of a pair } \rightarrow \\
\text { imperfectivisation } a / v a / i v a\end{array}$ \\
\hline $\begin{array}{l}\text { inherently atelic ipfs: full } \\
\text { suppletion } \\
\text { govorit'|skazat' }\end{array}$ & $\begin{array}{l}\text { inherently atelic ipfs (telicity is } \\
\text { obtained by addition of an argument) } \\
\text { pet'|spet', pisat'|napisat' (15 pref.) }\end{array}$ & $\begin{array}{l}\text { thematic suffix } \\
\text { rešit'|rešat' }\end{array}$ \\
\hline $\begin{array}{l}\text { inherently telic ipfs: full } \\
\text { suppletion } \\
\text { brat' }\left.\right|_{\text {vzjat }} \text {, }\end{array}$ & $\begin{array}{l}\text { inherently telic ipfs } \\
\text { staret'|postaret' } \\
\text { rasti|vyrasti }\end{array}$ & $\begin{array}{l}\text { dat'ldavat'(addition of a prefix to } \\
\text { the ipf } \mathrm{v} \text { doesn't change its aspect) }\end{array}$ \\
\hline $\begin{array}{l}\text { stress } \\
\text { nasypAt'|nasYpat' }\end{array}$ & $\begin{array}{l}\text { perfectivisation of bi-aspectual } \mathrm{v} \\
\text { asfal 'tirovat' } \rightarrow \text { zaasfal tirovat' }\end{array}$ & $\begin{array}{l}\text { second imperfectivisation } \\
\text { perečitat'|perečityvat' }\end{array}$ \\
\hline $\begin{array}{l}\text { inherently telic ipfs: partial } \\
\text { suppletion - postfix } \\
\text { ložit'sja } \mid \text { leč' } \\
\text { sadit'sja } \mid \text { sest' }\end{array}$ & & \\
\hline $\begin{array}{l}\text { inherently telic ipfs: partial } \\
\text { suppletion - mobile root vowel } \\
\text { ubirat' } \mid \text { ubrat' } \\
\text { snimat' } \mid \text { snjat' }\end{array}$ & & \\
\hline
\end{tabular}

Grammatical Pole

Table 5. Distribution of aspectual pairs

Verbs differing in prefixes as well as suppletives approach the lexical side of the continuum of the aspectual opposition and may be considered the two different lemmas. Verbs differing in suffixes approach (within the horizontal axe) the grammatical pole of the continuum and may be treated as a pure-aspectual unit, i.e. the two forms of the one lemma.

\section{$2 \quad$ Data}

This study in progress is based on the data from four children: one girl and three boys. The three boys, Roma (R.), Vanja (V.), and Vitja (Vi.) are the only children (during the period of recordings) in the middle-class families in St. Petersburg, where the standard version of colloquial Russian is spoken. Liza (L.) is the second child. Three children were more or less systematically recorded and/or video-taped two-five hours a month, from the onset of speech

21 As the other data show, cf. Ceytlin 2000, the type 2.1. occurs and develops around the age of 4-5 years and below. Children acquiring Russian as L1 do errors in the formation of aspectual pairs even with 7-8 years. 
till the age of three (and beyond). ${ }^{22}$ The data have been transcribed immediately (or shortly) after the recordings took place. ${ }^{23}$ The mean length of recordings per month is about 150 minutes (2.5 hours). During the period of crucial lexical and inflectional development, recording sessions reached six hours a month. These sessions were unified into two or three sections so that each section of the data per month has (a) relatively equal quantity, and (b) the minimal interval between the sessions (more about the data see Gagarina 2003).

For the purpose of the present study I analysed a limited amount of data, covering the period of five months from the onset of verb production. ${ }^{24}$ The interval of five months has not been chosen randomly. Previous studies have shown that Russian-speaking children start to master the productive use of verbal inflection at around the third month after the first verbs occur (cf. Gagarina 2003). So, the interval of five months captures the crucial period of the development of verbal inflection from its onset, when children produce rote-learned forms, to the beginning of the more 'advanced' level, the level of mastering grammatical rules. This is important to keep in mind in the analyses described below: the first three-four months reflect the grammatical system of a child during the (unstable) period of the establishing of morphological rules, lexical and inflectional spurts, etc.; the last month represents the more stable system, which is closer to the input.

Fig. 1 below shows the development of VU within the analysed period. Children start with a few verb instances and gradually approach the input level. Children's and adults' specific variation in the number of VU in relation to all AU are remarkable: V.'s input contains twice as many VU as L.'s input, $60,2 \%$ vs. $29,8 \%$. The variation in the production of VU mirrors the MLU in words in such a way that the lower the MLU the less VU are produced. Compare the MLU for the $5^{\text {th }}$ analysed month by three children V. 3.364, Vi. 3.475, L. 3.026 with the percentage of VU: V. 39,9\%, Vi. 51,5\%, L. 23,0\%. Any further analysis of VU is beyond the scope of this paper.

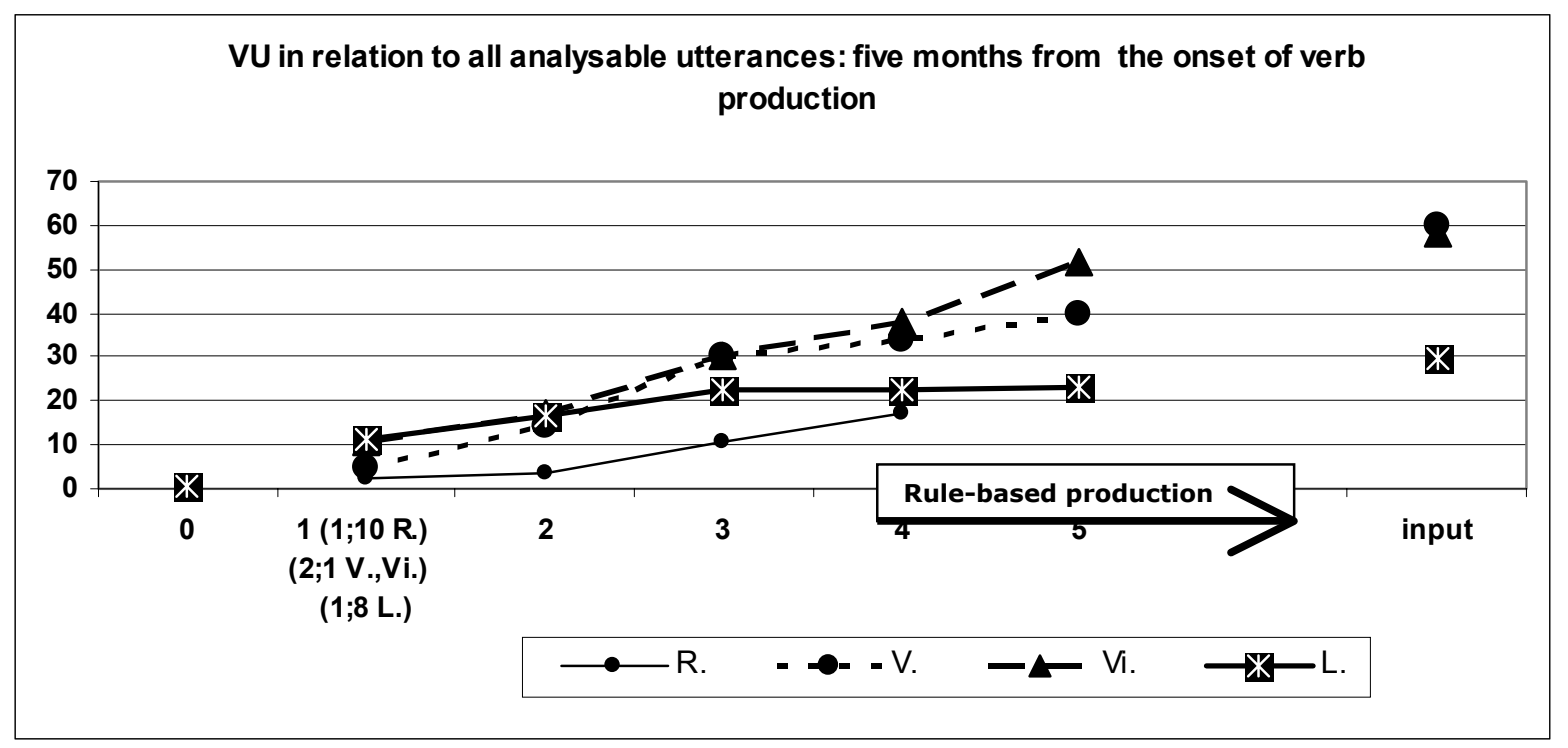

Fig. 1

22 The data of $\mathrm{R}$. have a gap of three months between $2 ; 2$ and 2;5 during the most crucial period of language development.

23 Transcription and coding of data was done in the CLAN format (MacWhinney 1995) by M. I. Akkuzina and E.K. Limbah.

24 In case of Liza I didn't include into the basic calculations the first month $(1 ; 7)$ when the only one instance of the verb otdaj 'give back-pf.imp.sg' has been documented. In case of Vitja first (non-distinctly pronounced) verbs occur at $2 ; 0$, but the recordings are available only from $2 ; 1$. 


\section{$3 \quad$ Results}

The preliminary results of this study in progress will be presented in two parts. The distribution of perfective and ipf verbs (types and tokens) and the inflections they obtain within five analysed months in the children's speech and input will be introduced in part one. The emergence of different types of aspectual pairs, quantitative analyses of ipf verbs forming pairs will be presented in part two. Possible implications of these results for the aspect acquisition theories will be discussed in the preliminary conclusion.

\subsection{Pfs and ipfs: quantitative comparison of types and tokens}

Pf and ipf verbs occur in speech production simultaneously. However, the previous study of the early verb lexicon (Gagarina (2000) investigating the first two dozen verbs in six children) had shown a slightly higher number of ipfs, which constitute $70 \%$ (in all children) in relation to all the verbs. It has been argued that children prefer ipfs, because they have a minimal stem complexity (a root and a thematic vowel/suffix) do not contain aspectual operators, and they are unmarked members of the privative opposition and are easier, then pfs, to operate with.

The present study shows that the proportion of pfs and ipfs differs significantly between the children already within the 'onset' recording/month ${ }^{25}$, when the number of $\mathrm{pf}$ and ipf lemmas reaches 4 (R.), 10 (Vi.), 13 (V.), and 10 (L.) instances ${ }^{26}$. In this first analysed month ipfs produced by three children constitute $50 \%$ to $60 \%$ of all verbs (except for R.- $25 \%$ of all the verbs). Further changes of the proportion between ipfs and pfs may be considered to be 'learner-specific': developmental curves of $\mathrm{V}$. and L. behave relatively similarly, but in L. the number of ipf verbs is always circa $10 \%$ higher (except for the $4^{\text {th }}$ month when the difference is $20 \%$ ) than those produced by Vi. It is worth noting that, typically, the proportion between ipfs and pfs in production basically resembles the situation in the input - I found the 'monthto-month' correlation. This correlation is especially notable within the last analysed month, when the children's verb morphology resembles the target system most closely. Within this $5^{\text {th }}$ month, the number of ipfs in relation to VU in production is the closest to that of the input: V. 51,7\% and 51,5\% (input), Vi. 46,2\% - 40\% (input), L. 56,5\% and 60,4\% respectively.

The minor adult-specific peculiarities in the proportion of verbs of two aspects are registered: the pfs by L. outnumber ipfs by Vi. by about $20 \%$. This input difference generally reflects the 'speech-strategy' of adults: commenting on resultative events (Vi.) or on on-going events (L.).

25 The first verbs occur with four children at (slightly) different ages: R. at 1;10 and L. at 1;8 (I omit here 1;7, when only one verb token otdaj' 'give-back-imp' has been documented); V. and Vi. at 2;1.

26 The number of registered lemmas may partially depend on the length of recordings. But, taking into consideration that the data of V. are highly-dense: at 2;1 AU amount to 1160 , I found only 13 diverse lemmas. This figure is comparable with L.'s and Vi.'s verb production, 117 and 332 AU respectively. 


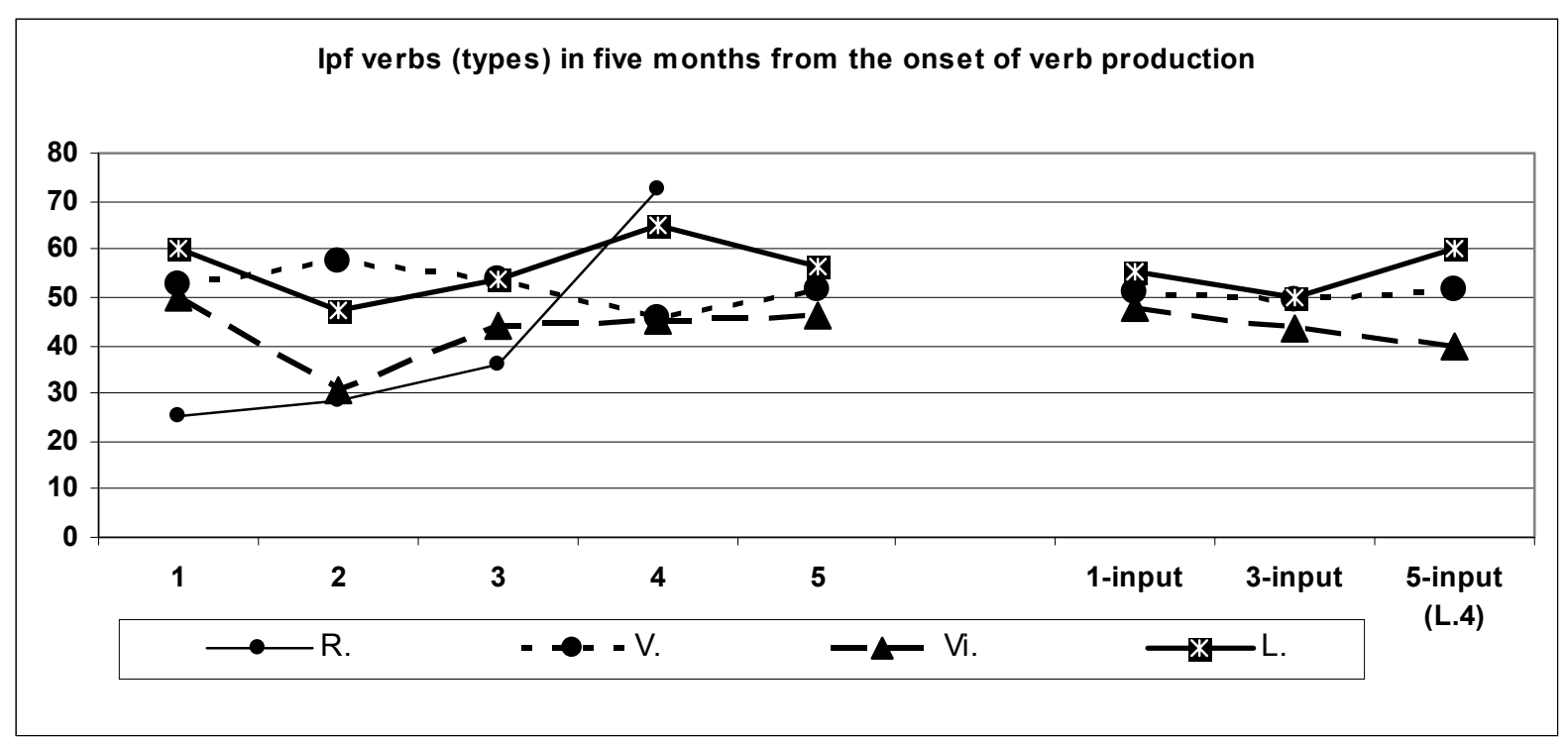

Fig. 2

Among the first dozen, verbs five are common for all the children: ipfs spat' 'sleep' and idti 'go by foot', pfs dat' 'give', upast' 'fell down' and odet' 'dress'.

In the bigger lexicon which children have mastered by the third month after the onset of verb production, ipf telic verbs and verbs of motion comprise the majority of all ipfs: idti 'do by foot - one-directional', stroit' 'build' (V), chistit' 'clean', kopat' 'dig', lovit' 'catch', myt' 'wash', sobirat' 'collect' (L.), pit' 'drink' (Vi.). Atelic ipf verbs are more rare: risovat' 'draw', stojat' 'stand', sidet' 'sit', guljat' 'walk', igrat' 'play', katat'sja 'roll' (V.), smotret' 'look' (Vi). Pfs ${ }^{27}$ are represented by the following verbs: sest' 'sit down', slezt' 'come/get down', uskakat' 'jump away', zalezt' 'climb on' (L.), slomat' 'break', otdat' 'give back', otkryt' 'open', vzjat' 'take' (R.), etc.

\subsection{Inflection of pfs and ipfs}

The first verbs of both aspects are used by four children in imperative, infinitive (with imperative meaning), and indicative, e.g. sjad' 'sit down-imp' sobirat' 'collect-inf', etc. In the early verb acquisition the morphological aspect strongly correlates with the occurrence of certain inflectional endings: the absolute majority of the $\mathrm{pf}$ verbs $^{28}$ denoting resultative actions which are perceived by the child attach the inflectional suffix of the past $-l$, e.g. upal 'fell down-sg:masc', slomal 'broke-sg:masc', etc. the ipf verbs denoting ongoing actions, processes, as well as intentions are used in the present with the appropriate person/number inflection, e.g. kapaet 'dig-3s', kataet 'roll-3s', spit 'sleep-3s' ${ }^{29}$ Thus, two contrastive types of here-and-now situations, ongoing and terminated (with a clearly perceived endpoint/endstate, after which a given action cannot be prolonged anymore), are consequently denoted by ipfs marked for present and pfs marked for the past. So, the two types of contrastive verb forms which children employ do not really reflect the presence of these two tenses, but indicate aspectual distinctions. However, this does not mean that children 'mistakenly analyse tense morphology as grammatical aspect to satisfy the principle of

27 No perfectiva tantum was registered in the data.

28 These verbs possess an ipf counterpart without a prototypically progressive meaning, padat' 'fell-ipf, lomat' 'break-ipf'.

29 The same tendency has been reported also for other children learning Russian: Gvozdev 1949; Gagarina 1997; Poupynin 1998. 
economy' (Weist et al. 2004:57); the above mentioned correlation between tense and aspect is also typical for adult Russian speech.

With the developing verb production, connections between verbs of $\mathrm{pf}$ or ipf aspect and tense marking become weaker but, as the further analyses will show, the tense/aspect cluster does not totally disappear from children's speech. Within the end of the second - beginning of the third month after the onset of verb production, ipf verbs start to obtain past tense inflections and are used to denote two types of past events:

a) on-going, e.g. chistila 'clean-sg:fem' (L. 1;9), sobirala 'gather-sg:masc' (L. 1;9), guljali 'go for a walk-pl' (V. 2;3), chinil 'repair-sg:masc' (Vi. 2;5) and

b) generalised-factual (telic), e.g., brala 'take-sg:fem' (V. 2;2). However, such uses are still very rare, see Table 6 .

\begin{tabular}{|c|c|c|c|}
\hline Children & Age & Types & Tokens \\
\hline Vi. & $2 ; 4$ & 3 & 3 \\
\hline & $2 ; 5$ & 2 & 3 \\
\hline V. & $2 ; 3$ & 5 & 6 \\
\hline & $2 ; 4$ & 4 & 5 \\
\hline & $2 ; 5$ & 5 & 8 \\
\hline
\end{tabular}

Table 6. Types and tokens of the ipf verbs with past tense inflection: Vi. and V.

Pf verbs with a person/number inflection (denoting near future) are documented with approximately the same lag of two-three months from the onset of verb production and are also represented by very few instances, e.g. R. 2;0 poedu and poedem 'go by car-fut:1s and 2p', Vi. 2;2 otkroju 'open-fut:1s, V. 2;4 vletit 'fly in-fut:3s', L. 1;10 popisaju 'do a poofut:1s'.

A similar tendency is found in the input of the three children. I compared the proportion of $\mathrm{pfs}$ and ipfs marked for future and past, respectively, see fig. 3.: ipf verbs marked for the past tense range between $7,9 \%$ and $18,2 \%$ of all ipfs, while ipf with the present tense inflection range between $51,7 \%$ and $70,8 \%$. The difference between various inflections of pfs is also substantial, although not as significant (cf. prototypical account of Andersen and Shirai 1996).

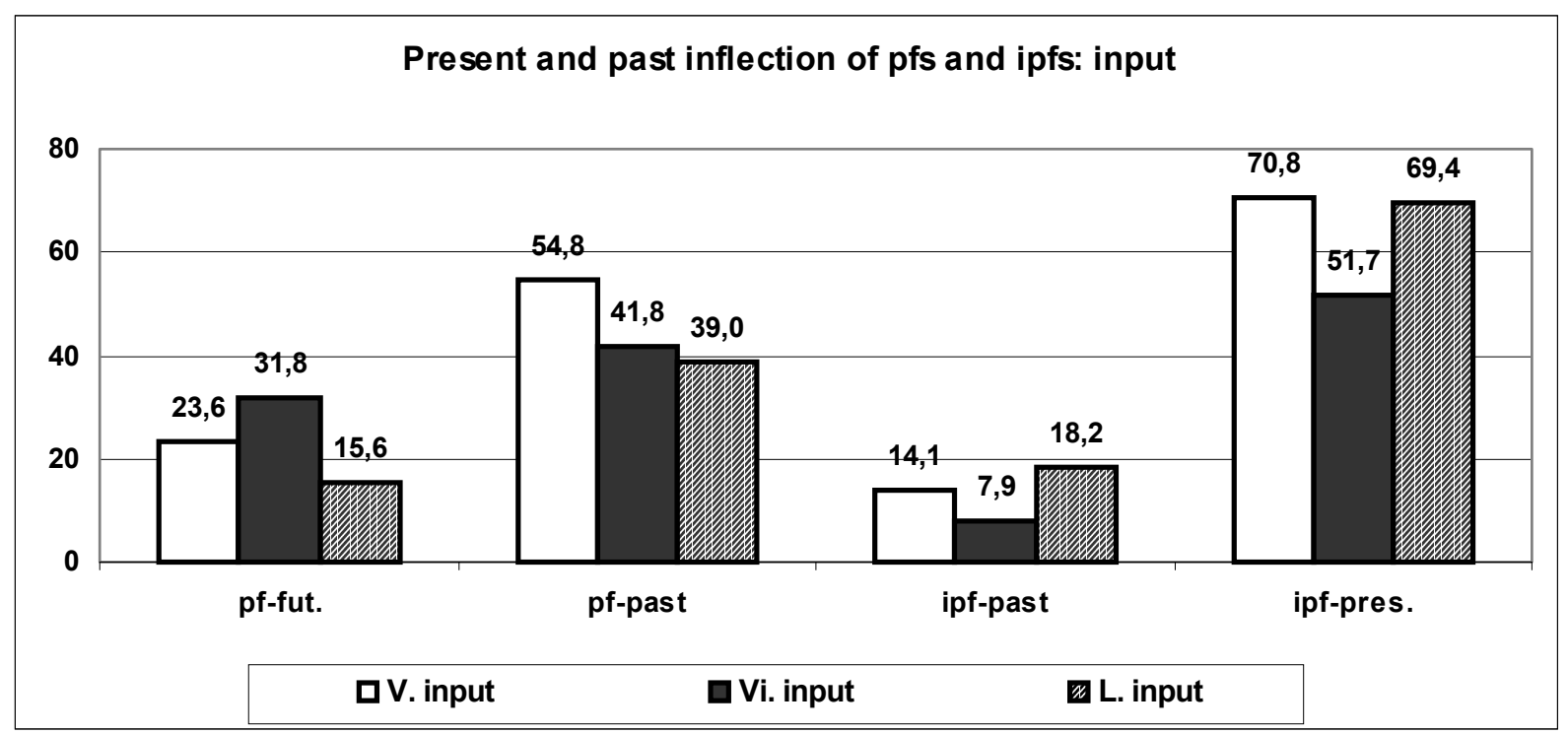

Fig. 3 
So, the Russian data show the strong connection between the pf and ithe pf aspect (strongly dependent on inherent semantics of verbs, Aktionsart) and tense marking. Similar correlation between lexical aspect and tense marking has been reported for other languages as well, e.g. Antinucci and Miller (1976) for Italian and English, Stephany (1981) for Greek, Aksu-Koç (1988) for Turkish, Shirai \& Anderson (1995) for English, Champaud et al. (1997) for French, etc.

\subsection{Aspectual pairs}

Studies on the acquisition of finite forms and/or verbal inflection usually explicate that while considering the transition from item-based phase to rule-based phase and the development of the latter, it is important to take into consideration the presence of the contrastive finite forms of one lemma (on criteria for productivity see, for example, Brown 1973, MuellerGarthercole, Sebastian, \& Soto 1999, Bittner et al. 2003). Notably, studies on the acquisition of aspect in Slavic languages show less attention to the emergence and development of aspectually contrastive forms of one lemma, i.e. counterparts. The next section deals with the quantitative and qualitative analyses of aspectual pairs. I analyse the emergence and the growth of aspectual pairs in the data of the three children, their structural and lexical type, and the inflection of counterparts forming pairs. ${ }^{30}$ Aspectual pairs occur with one to two months lag after the emergence of first verbs when children's lexicon reaches more than forty lemmas, see table 2 .

\begin{tabular}{|c|c|c|c|c|c|c|c|c|}
\hline & & $\begin{array}{c}\text { emergence } \\
\text { of verbs }\end{array}$ & $\begin{array}{c}2^{\text {nd }} \\
\text { month }\end{array}$ & $\begin{array}{c}3^{\text {rd }} \\
\text { month }\end{array}$ & $\begin{array}{c}4^{\text {th }} \\
\text { month }\end{array}$ & $\begin{array}{l}5^{\text {th }} \\
\text { month }\end{array}$ & total & $\begin{array}{l}\% \text { of aspectual pairs in } \\
\text { relation to verb lemmas }\end{array}$ \\
\hline \multirow[t]{3}{*}{ R. } & Age & $1 ; 10$ & $1 ; 11$ & $\begin{array}{l}2 ; 0 \mathrm{a} \\
2 ; 0 \mathrm{~b}\end{array}$ & $2 ; 1$ & & & \\
\hline & $\begin{array}{l}\mathrm{N} \text { of aspectual } \\
\text { pairs }\end{array}$ & - & - & - & 2 & & 2 & \\
\hline & $\begin{array}{l}\mathrm{N} \text { of verb } \\
\text { lemmas }^{31}\end{array}$ & & & & & & & \\
\hline \multirow[t]{3}{*}{ V. } & Age & $\begin{array}{l}2 ; 1 \mathrm{a} \\
2 ; 1 \mathrm{~b} \\
2 ; 1 \mathrm{c}\end{array}$ & $\begin{array}{l}2 ; 2 \mathrm{a} \\
2 ; 2 \mathrm{~b} \\
2 ; 2 \mathrm{c}\end{array}$ & $2 ; 3 a$ & $2 ; 4 a$ & $2 ; 5 a$ & & \\
\hline & $\begin{array}{c}\mathrm{N} \text { of aspectual } \\
\text { pairs }\end{array}$ & - & 2 & 5 & 6 & 3 & 16 & 5,7 \\
\hline & $\mathrm{N}$ of verb lemmas & 16 & 37 & 54 & 78 & 96 & 281 & \\
\hline \multirow[t]{3}{*}{ Vi. } & Age & $2 ; 1$ & $2 ; 2$ & $2 ; 3$ & $2 ; 4$ & $2 ; 5$ & & \\
\hline & $\begin{array}{c}\mathrm{N} \text { of aspectual } \\
\text { pairs }\end{array}$ & - & - & 3 & 4 & 10 & 17 & 7,7 \\
\hline & $\mathrm{N}$ of verb lemmas & 10 & 13 & 41 & 64 & 91 & 219 & \\
\hline \multirow[t]{3}{*}{$\overline{\mathrm{L} .}$} & Age & $1 ; 8$ & $\begin{array}{l}1 ; 9 \mathrm{a} \\
1 ; 9 \mathrm{~b} \\
1 ; 9 \mathrm{c}\end{array}$ & $1 ; 10$ & $1 ; 11$ & $2 ; 0$ & & \\
\hline & $\begin{array}{l}\mathrm{N} \text { of aspectual } \\
\text { pairs }\end{array}$ & - & 3 & 4 & 2 & 2 & 11 & 5,8 \\
\hline & $\mathrm{N}$ of verb lemmas & 10 & 51 & 37 & 46 & 45 & 189 & \\
\hline
\end{tabular}

Table 7. Aspectual pairs and verb lemmas (types) in four children

30 Due to the small amount of R.'s data I omit them from the analyses in this part.

31 This tier shows the number of all the verbs, used by the child from the 'onset' month to the month of emergence of a pair. 
The first instances of the aspectual pairs belong to all three structural types: prefixation type lomat'|slomat '32 'break', risovat'|narisovat' draw (V.); suffixation odevat'| odet' (L.), and suppletion sadit'sjalsest' (Vi.). A finite ipf counterpart of a pair attaches 3 sg inflection and a finite pf counterpart attaches past tense inflection; further, forms of both aspects occur in infinitive and imperative.

Generally, the total number of aspectual pairs within 5 analysed months is not high, see Table 2: V. -16, Vi. - 17, and L. 11. Children (and adults) produce a surprisingly modest amount of aspectually distinctive forms of one lemma. This is well exemplified in Fig. 4, which shows the proportion between aspectual pairs and all verbs produced by children and adults. ${ }^{33}$ Although adults utter more aspectual pairs (mean 19\%) than children (mean 10\%), both percentages are still very low.

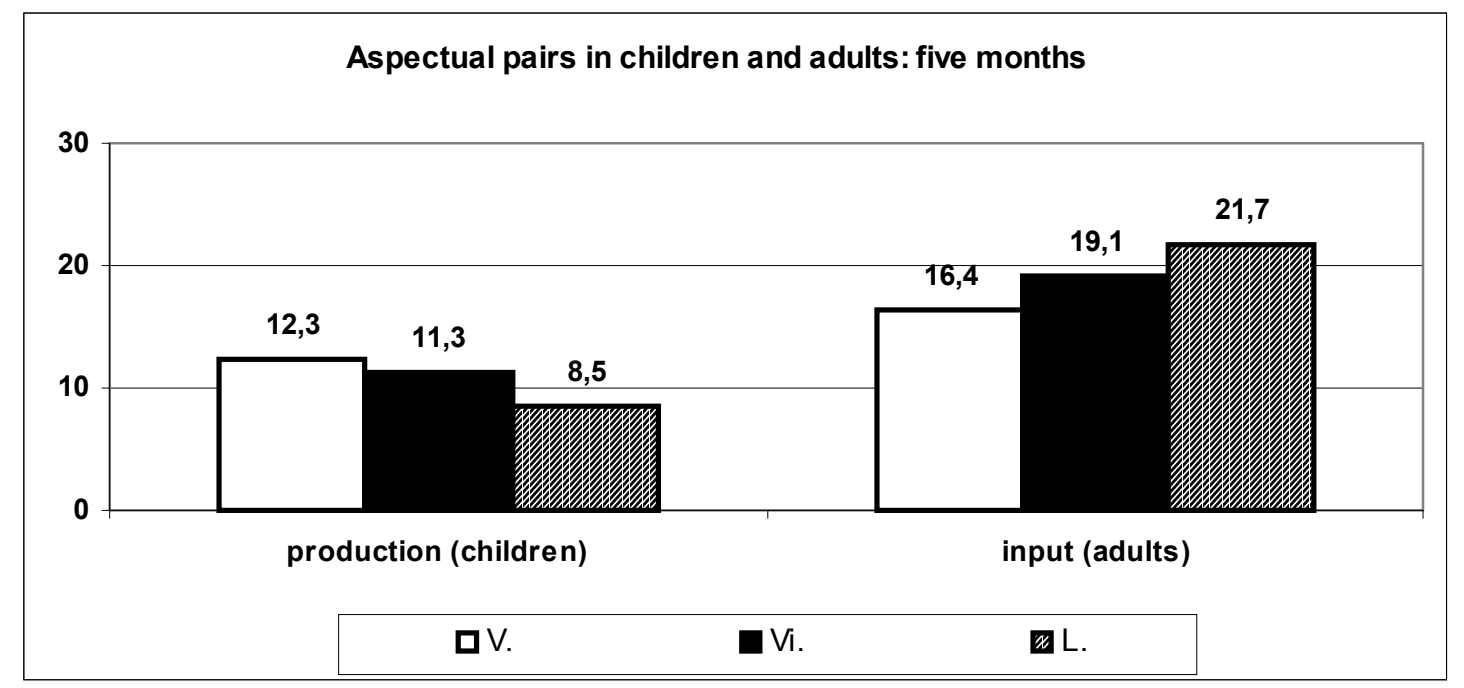

Fig. 4

Within the pairs used by children at the end of the analysed period, the above-mentioned tendency in distribution of the past and present tense inflection is also observed: the pfs cluster with the past and the ipf - with the present ${ }^{34}$, both forms are also used in the infinitive and the imperative. Consider the aspectual pairs lomat'|slomat' 'break-ipflpf' (Vi.), examples 4a, 4b and vstavat'|vstat' 'stand up-ipflpf' (V.), examples 5a-5e:

$(4 a)^{35}<$ vi204>

*VIT: Slomali

dom.

\%mor: V|slomat'\&PFV:TRANS-PAST:PL $\quad$ N|dom\&INANI:MASC-SG:ACC

\%eng: broke

house

(4b) $<$ vi205 $>$

*VIT: [O], lomaet.

\%mor: [INTERJ|o] V|lomat'\&IMPF:TRANS-PRES:3S

\footnotetext{
32 In all the pairs ipf form is given before the backslash and pf - after the backslash.

33 It is necessary to have in mind that approximately one third of verbs don't form aspectual pairs.

34 Cf. with the prototype account of Shirai \& Andersen 1995.

35 Examples below are given in CHAT format, see MacWhinney 1995. For tagging see Voeikova 2000, Gagarina et al. 2003.
} 
(as the answer to the question (Tjotja) sobachku delaet? 'The woman is making the dog?'),

\%eng: ah is-breaking

V. uses ipf vstavat' in imperative (example 5a), also erroneously (example $5 \mathrm{~b})^{36}$ :

(5a) $<$ v204>

*VAN: Vstavaj,

[Vanja], chaj

pit'.

\%mor: V|vstavat'\&IMPF:INTRANS-IMP:SG [Vanja] N|chaj\&INANI:MASC-SG:ACC V|pit'\&IMPF:TRANS-INF

\%eng: stand-up [Vanja], tee

drink-inf

(5b) $\quad<\mathrm{v} 203>$

*VAN:Vstavaj@error

mashiny.

\%mor: V|vstavat'\&IMPF:INTRANS-IMP:SG

$\mathrm{N} \mid$ mashina\&INANI:FEM-PL:NOM

\%eng: stand-up

cars

and pf vstat' as infinitive with negation and in the past:

(5c) $<$ v203 $>$

*VAN: $\mathrm{Ne}$ vstat'.

\%mor: PTL|ne V|vstat'\&PFV:INTRANS-INF

\%eng: not stand-up

*VAN: Vstal.

\%mor: V|vstat'\&PFV:INTRANS-PAST:SG:MASC

\%eng: stand-up

(5d) $\quad<$ v204>

*VAN: Vstala

sjuda.

\%mor: V|vstat'\&PFV:INTRANS-PAST:SG:FEM

ADV $\mid$ sjuda

\%eng: stand-up

here

(5e) $<$ v205>

*VAN: Vot,

vstal.

\%mor: PTL|vot

V|vstat'\&PFV:INTRANS-PAST:SG:MASC

\%eng: well

stand-up

The data show that, at least in three L1 Russian-speaking children counterparts of an aspectual pair are 'fixed' with a specific inflection. Moreover, the whole pair may be biased towards (or predisposed for) a specific situation/context. This tendency may be stronger or

36 Another observation is that it seems that children make more mistakes in inflection with the verbs constituting aspectual pairs. 
weaker depending on the lexical type (and telicity) of verbs compiling a pair (cf. Lehmann 1993, $\alpha$ - and $\beta$-verbs of an aspectual pair). Hypothetically, for pairs, whose counterparts denote accomplishments with a perceptively clear shorter duration, the pf should be employed more frequently to designate the telic resulting events than its ipf counterpart. Exactly the same tendency is exhibited in the analysed data: the children employ only one, prototypical, basic member of an aspectual pair (in Lehmann's terminology $\alpha$-verb). The other, marginal member is used rarely in a restricted set of contexts and is much more dependent on these contexts. Interestingly, Polinsky (2000) makes a similar observation about the speech of Russian immigrants in the USA:

aspectual pairs ... are practically non-existent. American Russian abandons such pairs in favour of lexicalized perfectives or imperfectives. Which of the aspectual forms is lexicalized is heavily determined by the telicity of a given verb ... (Polinsky 2000:456457).

Consider the pair padat'lupast' 'fall-ipflpf': the pf is used 63 times and the ipf - only once (in a generic meaning) in V.'s data. ${ }^{37}$ The usage of padat'-ipf is enforced by the questions of adults, children seldom describe situations when something is in the process of falling, but more the observable result, see examples $6 \mathrm{a}-6 \mathrm{~g}$ :

(6a) $<$ vi203 $>$

*VIT: Vitja

upal.

\%mor: N|vitja\&ANI:MASC-SG:NOM

V|upast'\&PFV:INTRANS-PAST:SG:MASC

\%eng: Vitja

fell-down

(6b) $<$ v203>

*VAN: Upala

tetja.

\%mor: V|upast'\&PFV:INTRANS-PAST:SG:FEM

N|tetja\&ANI:FEM-SG:NOM

\%eng: fell-down

aunt/woman

(6c) $<1109>$

*LIZ: Upala.

\%mor: V|upast'\&PFV:INTRANS-PAST:SG:FEM

\%eng: fell-down

Only one instance of ipf is found by Vi. And V.

(6d) <vi205>

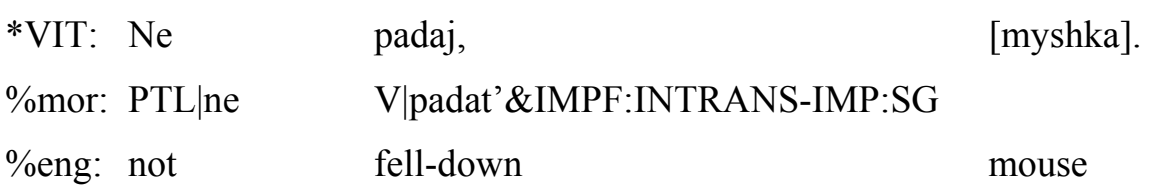

(6e) $<$ v203>

$\begin{array}{lll}\text { *VAN: Vot e ta } & \text { padaet } & \text { tozhe. } \\ \text { \%mor: PTL|vot PRO|e } \sim \text { tot\&-SG:FEM:NOM } & \text { V|padat'\&IMPF:INTRANS-PRES:3S } & \text { ADV|tozhe } \\ \text { \%eng: this } & \text { fell-down } & \text { also }\end{array}$

37 Approx. a similar proportion of token frequency of pf and ipf is seen by the two other children. 
and two instances are found by L.

(6f) $<1110>$

*LIZ: Padaet.

\%mor: V|padat'\&IMPF:INTRANS-PRES:3S

(situation: L. wrongly placed the toy on the lid and watches it misbalancing and falling down).

\%eng: fell-down

(6g) $<1111>$

*LIZ: Padaet.

\%mor: V|padat'\&IMPF:INTRANS-PRES:3S

(is used instead of fly as the answer to the mother's question What the boy is doing?)

\%eng: fell-down

If counterparts of a pair denote events with longer duration (e.g. constructive and destructive verbs) perceived/performed by a child, the token frequency of the ipf and the pf in such pair is rather similar. ${ }^{38}$ Consider the pairs from V.'s data stroit'lpostroit' 'build-ipflpf': token frequency is $2 \backslash 3^{39}$, chinit'|pochinit' 'repair-ipflpf': token frequency is $9 \backslash 10$, examples $7 \mathrm{a}-7 \mathrm{~g}$.

(7a) $<\mathrm{v} 201 \mathrm{c}>$

*VAN: [Baba], stroj $\quad$ vorota.

\%mor: $\quad$ V|stroit'\&IMPF:TRANS-IMP:SG $\quad$ N|vorota\&INANI-PL:ACC

\%eng: grandmother, build gates

(7b) $\quad<$ v203 $>$

*VAN: Ogromnyj postroil,

ogromnyj dom.

\%mor: ADJ|ogromnyj\&-SG:MASC:ACC V|postroit'\&PFV:TRANS-PAST:SG:MASC

ADJ|ogromnyj\&-SG:MASC:ACC $\quad$ N|dom\&INANI:MASC-SG:ACC

\%eng: huge built,

huge house

(7c) $\quad<$ v204>

*VAN: Mama stroila.

\%mor: N|mama\&ANI:FEM-SG:NOM V|stroit'\&IMPF:TRANS-PAST:SG:FEM

\%eng: mother was-building

(7d) $<$ v202 $>$

*VAN: Chini, [baba]

\%mor: V|chinit'\&IMPF:TRANS-IMP:SG

\%eng: repair, [grandmother]

38 The bias towards a specific event in such aspectual pairs is not strong.

39 Analysing a pf member of such pairs one has to pay attention to possible omission of prefixes. 
(7e) $\quad<$ vl204 $>$

*VAN: Mashinu

\%mor: N|bezinju\&INANI:FEM-SG:ACC

chinit'

net.

\%eng: car

V|chinit'\&IMPF:TRANS-INF PRED|net

repair

not

(7f) $<$ vl204>

*VAN: Pochini.

\%mor: V|pochinit'\&PFV:TRANS-IMP:SG

\%eng: repair

(7g) <vl204>

*VAN: Pochinil.

\%mor: V|pochinit'\&PFV:TRANS-PAST:SG:MASC

\%eng: repair

Finally, for pairs, whose counterparts denote activities and accomplishments, the token frequency of ipf and pf is also more similar, e.g. Vi. exat'lpriexat' 'go by car', the token frequency is $7 \backslash 5$.

For each child the verb lemmas were summarised for all the five months of the verb production (see Table 2) and aspectual pairs were extracted from this total amount of the lemmas. In sum, 23 types of aspectual pairs were documented in all the children. These pairs belong to each of the three 'structural types' - 6 suppletives:

\begin{tabular}{|c|c|c|}
\hline ipf & pf & translation \\
\hline govorit' & skazat' & speak \\
\hline iskat' $^{\prime}$ & najti & look for \\
\hline padat' & upast' & fell \\
\hline sadit'sja & sest' $^{\prime}$ & sit down, seat oneself \\
\hline snimat' & snjat' & undress \\
\hline sazhat' & posadit' & seat somebody \\
\hline
\end{tabular}

7 suffixation:

\begin{tabular}{|c|c|c|}
\hline ipf & pf & translation \\
\hline odevat' & odet' $^{\prime}$ & dress on \\
\hline odevat'sja & odet'sja $^{\prime}$ & dress on - reflex. \\
\hline otdavat' $^{\prime}$ otdat' $^{\prime}$ & give up \\
\hline otkryvat' & otkryt' & open \\
\hline vkljuchat' & vkljuchit' & switch on \\
\hline vstavat' & vstat' & stand up \\
\hline zalezat' & zalezt' & climb \\
\hline
\end{tabular}

10 prefixation:

\begin{tabular}{|c|c|c|}
\hline ipf & pf & translation \\
\hline bit' & ubit' & kill \\
\hline chinit' $^{\prime}$ & pochinit' & repair \\
\hline
\end{tabular}




\begin{tabular}{|c|c|c|}
\hline est' & s'est' & eat \\
\hline exat' & priehat' & go by car \\
\hline idti & prijti & go by foot \\
\hline lomat' & slomat' & break \\
\hline lomat'sja & slomat'sja & break - reflex. \\
\hline nesti & prinesti & carry \\
\hline pit' & popit' & drink \\
\hline risovat' & narisovat' & draw \\
\hline
\end{tabular}

No significant preference is given to either structural type, although pairs formed by prefixation are more frequent than those formed with suffixation and suppletion. The low variety of verbs used with both aspects, i.e. aspectual pairs, makes it difficult to survey the regularities in the use of a given type. One needs more data to evaluate any existing tendencies. At the present time, the following observation may be made: different structural types of pairs are represented in the data and no preference for any type is evident. It seems that the inherent lexical meaning (and telicity) of a verb, the structural complexity of a pair and the sentential context (apart from the frequency and the saliency in then input) are more essential for the acquisition (and the funrtioning) of the aspectual counterparts than the type of a morphological operator deriving a respective pf or ipf verb.

\section{$4 \quad$ Discussion and conclusion}

In this paper I have analysed the emergence and the development of the ipf and pf verbs and their inflections, as well as the aspectual pairs in four L1-speaking Russian children. No common significant tendency for the preference of verbs of either aspect was found in the early lexicon. The proportion between ipfs and pfs in the speech production basically resembles the situation in the input: month-to-month correlation was registered. Similarities in the production of $\mathrm{pf}$ and ipf verbs in adults and children may be explained by the peculiarities of the adult-child communication in which a) the same events are discussed by the adults and the children, b) children answer questions of adults which already presuppose the use of a certain aspect. Both the adults and the children show a preference for the use of pf verbs with the past tense inflection and ipf verbs with the present tense inflection, i.e. tense/aspect cluster.

Much space was devoted in this paper to the treatment of aspectual pairs and their types but it turns out that the number of aspectual oppositions in both child and adult recorded speech is tremendously low. Children are scarcely able to use aspectual pairs in a productive manner even when they productively use verb forms of both aspects in the past, present ${ }^{40}$ and future and their speech resembles the input. Does it mean that the acquisition of aspectual oppositions, i.e. aspectual pairs, is not relevant for the issues dealing with the acquisition of the aspect and with the emergence of productivity? Does it mean then, that aspect is acquired verb-specifically alongside with the lexical meaning of the verb lemmas (as a lexical and not grammatical category) during a longer period of time? Do children (and adults) generally need aspectual counterparts in their communication (or are aspectual pairs redundant in the communication between care-takers and children)?

\footnotetext{
40 Remember, that only ipf verbs may be marked for the present.
} 
The data show that children make the correct choice of the pf or the ipf aspect in denoting different types of situations from the onset of the verb production. ${ }^{41}$ They also correctly use the counterparts of rarely observed aspectual pairs. This may serve as evidence for early understanding and for early grammaticalisation of aspectual meanings. Further, aspect is intertwined with the lexical meaning and is learned as an indispensable part of it (and not a separate category), ${ }^{42}$ since it deals with the boundaries of situations (cf. Lamb, Bornstein, \& Teti 2002 on the importance of figures' boundaries for the early perception and gathering of the information

newborns seem to focus most of their attention on the boundaries of figures, where the greatest amount of information is contained (Lamb, Bornstein, \& Teti 2002:176)).

Children learn to recognise and to 'name' situations by means of various verbs (by employing the lexical meaning) and simultaneously they learn to code boundaries of events by means of the verbal aspect. If one accepts Bloom, Lifter, \& Hafitz's (1980:405) suggestion that situations have 'inherent aspectual meaning', then it is not surprising that aspectual pairs are very infrequent in spontaneous speech and that they are not an essential element of children's early communication. Various verbal lemmas may be said to be (proto)typical (or more natural) for either the pf or ipf aspect, e.g. spat' 'sleep' is typical (natural) for the ipf aspect and upast' 'fall' for the pf aspect. Thus, the situation of 'sleeping' and the situation of 'falling' will be encoded much more frequently with ipf and pf verbs respectively. Investigations of aspectual pairs seem not to be relevant for determining the productive use of verbal aspect, but they are essential for studies of childrens' advanced linguistic systems, when children have mastered the productive use of finite verbs in multicomponent sentences.

Another question I asked in the study is how verbal aspect is learned. Whether aspect is learned as a rule may depend on the type of an aspectual pair and the contexts in which it is used. ${ }^{43}$ In example (8) all pfs verbs purely mark the boarder of the situation denoted by ipf form of the same lemma, i.e. the prefix po- merely points to the boundary/the end of the discussed event. In the contexts given below aspect may be learned as a rule (the pfs verbs are marked for the past.masc.sg):

$$
\begin{array}{llll}
\text { Ty } \text { poel? ...popil? } & \text {...poigral? } & \text {...pomyl ruki? ...poguljal } ? & \text {...pospal? } \\
\text { you eat? ...drink? } & \text {...play? } & \text {...wash hands? ...go for a walk? } & \text {...sleep? }
\end{array}
$$

'Are you ready with eating? ...drinking? ...playing? ...washing the hands? ...walking? ...sleeping?'

Since this study presents the intermediate results of the work in progress, the conclusions drawn from the analyses should be considered to be preliminary. More work has to be done on the investigation of contexts in which aspectual pairs and their members are used by children and adults, on the analyses of the relationship between aspectual meanings and sentential types and on the syntactic-semantic interface within a sentence.

41 It is known that adults learning Russian as a second language have great problems in the correct use of a pf or ipf aspect in a broad set of situations.

42 Probably the fact that the verbal aspect is mastered by children as a part of the lexical meaning of a verb within the general process of the cognitive development and is not learned as a separate verbal category explains the difficulties second language learners have with it.

43 Cf. Weist 2002:69 'In my opinion, any theory that tries to explain the acquisition of tense-aspect morphology without also providing an understanding of the acquisition of clause structure will prove to be inadequate'. 


\section{Natalia Gagarina}

\section{References}

Aksu-Koç, A. (1988): the Acquisition of Aspect and Modality: The Case of Past Reference in Turkish. Cambridge: Cambridge University Press.

Antinucci, F. \& R. Miller (1976): How children talk about what happened. Journal of Child Language 3, 169189.

Bar-Shalom, E. (2002): Tense and Aspect in Early Child Russian. Language Acquisition 10/4, 321-337.

Bittner, D., W. U. Dressler, \& M. Kilani-Schoch (2003): Introduction. In D. Bittner, W. U. Dressler, \& M. Kilani-Schoch (eds.): Development of Verb Inflection in First Language Acquisition. A Cross-Linguistic Perspective, 131-169. Berlin: de Cruyter.

Bloom, L., Lifter, K. \& Hafitz, J. (1980): Semantics of the verbs and the development of verb inflecrtion in child language. Language 56, 386-412.

Bondarko, A.V. (1983): Principy funkcional'noj grammatiki i voprosy aspektologii. Leningrad: Nauka. [The principles of functional grammar and the questions of aspectology]

- (1990): O znachenii vidov russkogo glagola. Voprosy jazykoznanija, 4, 5-24. [On the aspectual meanings of the Russian verb].

- (1995): Semantika glagol'nogo vida v russkom jazyke. In Beitrage zur Slavistik XXIV. Frankfurt am Main, Berlin, Bern, New York, Wien. [Semantics of aspect in Russian].

Brown, R. (1973): A First Language. Cambridge MA: Harvard University Press.

Ceytlin, S. N. (2000): Jazyk i rebjonok: Lingvistika detskoj reči. Moskva: VLADOS. [The language and the child: Language acquisition].

Čertkova, M. Ju. (1996): Grammaticheskaja kategorija vida v sovremennom russkom jazyke. Moskva. [The grammatical aspect in contemporary Russian]

Champaud, C., Dressler, W., U., Sedlak, M., Gagarina, N. (1997): Acquisition of verbal Categories in French, German, and Russian. Paper presented at the conference in Rennes, France in September 1997, ms.

Comrie, B. (1976): Aspect: an introduction to the study of verbal aspect. Cambridge: Cambridge University Press.

Dahl, Ö. (1974): Some suggestuins for a logic of aspects. In Slavica Gothoburgensia 6. Göteborg contributions to the seventh International Congress of Slavists in Warsaw, August 21-27, Göteborg.

Dowty, D. (1972): Studies in the logic of verbal aspect and time reference in English. Austin: University of Texas, Dissertation.

Filip, H. (1999): Aspect, Eventuality Types, and Noun Phrase Semantics. New York: Garland Publishing. Outstanding dissertations in linguistics.

Gagarina, N. (1997): Aspektual'naja semantika i funkcionirovanije vidov russkogo glagola v detskoj rechi. Unpublished PhD Dissertation, State Pedagogical University of Russia, St.Petersburg. [Aspectual semantics and functioning of the aspects of Russian verbs in language acquisition]

- (2000): The acquisition of aspectuality by Russian children: the early stages. ZAS Papers in Linguistics 15 , 232-246.

- (2001): Sovremennyje teorii ontolingvistiki o vide i vremeni glagola: protivorechija i puti ix razreshenija. In Shubik S.A. et al. (eds.): Issledovanija po jazykoznaniju: K 70-letiju chlena-korrespondenta RAN $A$. V. Bondarko, 337-346. St. Petersburg: SPbGU. [Contemporary ontolinguistic theories on the acquisition of tense and aspect: contradictions and the ways of their settling]

- (2002): Productivity of the verbal inflectional classes (the case of Russian). In K. Dziubalska-Kolaczyk \& J. Weckwerth (eds.): Future Challenges for Natural Linguistics, 153-164. Wien: Lincom.

- (2003): The early verb development and demarcation of stages in three Russian-speaking children. In D. Bittner, W. U. Dressler, \& M. Kilani-Schoch (eds.): Development of Verb Inflection in First Language Acquisition. A Cross-Linguistic Perspective, 131-169. Berlin: de Cruyter.

Gagarina, N., Voeikova, M., \& S. Gruzincev (2003): New version of morphological coding for the speech production of Russian children (in the framework of CHILDES). In P. Kosta, J. Blaszczak, J. Frazek, L. Geist, \& M. Zygis (eds.): Investigations into Formal Slavic Linguistics. Contributions of the Fourth European Conference on Formal Description of Slavic Languages, University of Potsdam.

Gvozdev, A. N. (1949): Formirovanije u rebenka grammaticheskogo stroja russkogo jazyka. Moscow: Akad. Pedag. Nauk RSFSR [The construction of the Russian grammatical system by the child].

Isačenko, A. V. (1968): Die russische Sprache der Gegenwart. Halle: VEB Max Niemeyer Verlag. 
Katičić, A. (2003): Early verb development in one Croatian-speaking child. In D. Bittner, W. U. Dressler, \& M. Kilani-Schoch (eds.): Development of Verb Inflection in First Language Acquisition. A Cross-Linguistic Perspective, 239-268. Berlin: de Cruyter.

Kiebzak-Mandera, D. (1999): Kształtowanie się systemu werbalnego u dzieci rosyjskojęzycznych: analiza porównawcza. Unpublished $\mathrm{PhD}$ Dissertation, Jagiellonian University. [The formation of the verbal morphology in Russian-speaking children: a comparative analysis]

Kucera, H. (1983): A semantic model of verbal aspect. In American contributions to the Ninth International Congress of Slavists. Vol. 1 Linguistics. Columbus, Ohio.

Lamb, M. M. Bornstein, \& D. Teti (2002): Development in Infancy. An Introduction. Mahwah, New Jersey, London: Lawrence Erlbaum Associates.

Lehmann, V. (1993): Die Russische Aspekte als gestufte kategorie (Ein Beispiel für die Bedeutung der kognitiven Linguistik in der slavistischen Sprachwissenschaft). In Die Welt der Slaven 38/2, 265-297. Universität München, Institut für Slavische Philologie.

MacWhinney, B. (1995). The CHILDES project: tolls for analysing talk. Hillsdale, NJ: Erlbaum.

Mehlig, H. R. (1981): Satzsemantik und Aspektsemantik im Russischen (Zur Verbklassifikation von Z. Vendler). Slavistische Linguistik 1980, 95 -151. München.

Mueller-Garthercole, V. C., E. Sebastian, \& P. Soto (1999): The early acquisition of Spanish verb morphology. Across-the-board or piecemeal knowledge? The International Journal of Bilingualism 3, 133-182.

Petruhina, E.V. (2000): Aspektual'nyje kategorii glagola v russkom jazyke v sopostavlenii s češskim, slovackim, pol'skim i bolgarskimi jazykami. Moscow: MGU. [Aspect Verb categories in Russian in comparison to Check, Slovak, Polish and Bulgarian languages]

Polinsky, M. (2000): A Composite Linguistic Profile of a Speaker of Russian in the U.S. In O. Kagan \& B. Rifkin (eds.): The learning and Teaching of Slavic Languages and Cultures, 437-465. Slavica: Bloomington.

Poupynin, J. A. (1998): Elementy vido-vremennoj sistemy v detskoj rechi. Voprosy jazykoznanija 2, 102-116. [The elements of tense and aspect in language acquisition]

Šaxmatov, A. A. (1941): Sintaksis russkogo jazyka. Leningrad: Učpedgiz. [Syntax of Russian]

Shirai, Y. \& R. Andersen (1995): The acquisition of tense-aspect morphology: A prototype account. Language, $71,743-762$.

Shirai, J. (1998): The emergence of thense/aspect morphology in Japanese: Universal predisposition. First Language 18, 281-309.

- (2003): The acquisition of tense-aspect morphology and the regular-irregular debate. ZAS Papers in Linguistics 29, 195-209.

Smoczyńska, M. (1985): The acquisition of Polish. In Slobin, D. I. (ed.): The crosslinguistic study of language acquisition, 595-686. Hillsdale: Lawrence Erlbaum.

Stephany, U. (1981): Verbal Grammar in Modern Greek Early Child Language. In P.S. Dale \& D. Ingram (eds.): Child Language: An International Perspective, 45-57. Baltimore, MD: University Park Press.

Stoll, S. (1998): The role of lexical Aktionsart for the acquisition of Russian aspect. First Language 18, 351-378.

Vendler, Z. (1967): Verbs and times. Linguistics in philosophy. Cornell University Press: Ithaca, New York.

Verkuyl, H. (1993): A Theory of Aspectuality. The Interaction between Temporal and Atemporal Structure. Cambridge: Cambridge University Press.

Vinogradov, V.V. (1938): Sovremennyj russkij jazyk. Grammaticheskoe uchenie o slove. M.: Učpedgiz. [Contemporary Russian]

Voeikova, M. (2000): Russian existential sentences: A functional approach. LINCOM Studies in Slavic Linguistics. München: LINCOM Europa.

Wagner, L. (2001): Aspectual Influences on Early Tense Comprehension. Journal of Child Language 28, 661681.

Weist, R. (2002): The first language acquisition of tense and aspect: A review. In R. Salaberry \& Y. Shirai (eds.): The L2 Acquisition of Tense-Aspect Morphology, 21-78. John Benjamins: Amsterdam.

Weist, R., H. Wysocka, K. Witkowska-Stadnik, E. Buczowska, \& E. Konieczna (1984): The defective tense hypothesis: On the emergence of tense and aspect in child Polish. Journal of Child Language 11, 347-374.

Weist, R., A. Pawlak, \& J. Carapella (2004): Syntactic-semantic interface in the acquisition of verb morphology. Journal of Child Language 31/1, 31-60.

Russkaja grammatika-80: Švedova, N. Ju. (ed.):, 1980. Moskva: Nauka, AN SSSR. 